\title{
Do firm boundaries matter? The impact of Chinese imports on US conglomerates
}

\author{
Ryoonhee Kim \\ School of Business and Economics, Soongsil University, Seoul, South Korea
}

\begin{abstract}
The purpose of this paper is to use China's World Trade Organization accession as a quasi-natural experiment and examine whether conglomeration affects firmss' ability to respond to a significant increase in competitive pressure. Conglomerate segments have higher sales growth and higher profitability than singlesegment firms, when they face intensified import competition. Conglomerates' outperformance is not observed when the markets in which segments operate already have high product market competition. Overall, conglomeration encourages competitiveness, and internal resources are allocated to relatively competitive segments.
\end{abstract}

Keywords China's World Trade Organization accession, Conglomerates, Import competition

Paper type Research paper

\section{Introduction}

Given the prevalence of conglomerates and business groups, how firm boundaries affect resource allocation has fascinated researchers. While early studies criticize conglomerates for diversification discount, others suggest that internal capital markets relax the financial constraints on conglomerate segments or group-affiliated firms, which explains why these firms engage more in corporate innovation (Belenzon and Berkovitz, 2010) and plant acquisitions (Maksimovic and Phillips, 2008) [1]. Gopalan and Xie (2011) demonstrate that conglomeration enables the segments to avoid financial constraints during industrial distress and, hence, to perform better during such times. Despite the large body of research, the differences in reaction to competitive threats between conglomerate segments and single-segment firms have not been explored.

Current studies do not clearly predict a competitive advantage for conglomerates over single-segment firms when faced with intense competition. Cestone and Fumagalli (2005) argue that when business group internal capital markets allocate more resources to subsidiaries facing tough competition, these firms more likely to enter or remain in the

(c) Ryoonhee Kim. Published in Journal of Derivatives and Quantitative Studies: 선물연구. Published by Emerald Publishing Limited. This article is published under the Creative Commons Attribution (CC BY 4.0) licence. Anyone may reproduce, distribute, translate and create derivative works of this article (for both commercial and non-commercial purposes), subject to full attribution to the original publication and authors. The full terms of this licence may be seen at http://creativecommons.org/ licences/by/4.0/legalcode

JEL classification - Classification: L22, L25

This work was supported by the Soongsil University Research Fund of 2019. The author also acknowledge financial support through a grant (CityU 11505415) from the Research Grants Council of the HKSAR Government and the City University of Hong Kong. Any remaining errors are author's own.

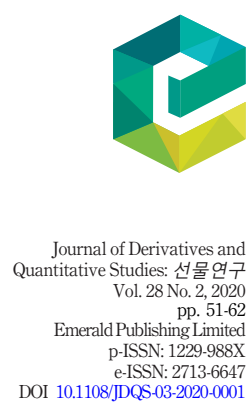


JDQS 28,2

market. Conversely, their model also suggests that internal resource reallocation hinders group-affiliated firms' competitiveness, when group headquarters engage in winner-picking owing to scarce resources. This is similar to the commitment cost of internal capital markets, as suggested by Matsusaka and Nanda (2002).

This study examines the product market outcomes of US firms using China's World Trade Organization (WTO) accession in 2001 as an event that significantly increased competition for firms. Using Compustat segment data for 1997-2006, this study reveals that, for industries facing an increase in Chinese imports, conglomerate segments show larger sales growth in 2002-2006. With a fixed market size in the short term, market shares increase for conglomerate segments and decrease for single-segment firms, and conglomerate segments outperform in terms of profitability. Finally, when market competition was not intense prior to the WTO access, conglomerates' outperformance is more pronounced. The result suggests that conglomerates engage in winner-picking and focus on core segments with promising prospects.

This study provides large sample evidence of conglomerates' outperformance using an exogenous shock to the level of import competition. This study is similar to Bai (2019) and Swanburg (2014), who examine conglomerate acquisitions and investments, respectively, compared to single-segment firms when import tariff rates are reduced. This study is consistent with Bai (2019), which documents conglomerates' higher resilience against tough competition. On the other hand, Swanburg (2014) shows that conglomerates reduce investments more than single-segment firms do. This study builds on Khanna and Tice (2001), who showed that conglomerates respond quicker when Walmart enters the market.

This study is also closely related to the literature that explores the effect of import competition on domestic firms [2]. Pierce and Schott (2016) and Bloom et al. (2016) examine the effect of Chinese import competition on US employment and European innovation in the period following China's WTO accession. This paper adds to the literature by documenting that Chinese imports can affect conglomerate and single-segment firms differently.

The remainder of the paper is organized as follows: Section 2 reviews the related literature. Section 3 explains the data and empirical methodology. Section 4 reports and discusses the empirical results. Section 5 concludes the paper.

\section{Related literature}

Since Coase (1937), researchers have studied the effect of firm boundaries on resource allocation. Several studies show that conglomerate segments' access to internal capital markets generates behaviors or values different than those of single-segment firms [3]. Group firms and conglomerates are shown to engage more in corporate innovation (Belenzon and Berkovitz, 2010) and plant acquisitions (Maksimovic and Phillips, 2008). Gopalan and Xie (2011) argue that conglomerate internal capital markets lead conglomerate segments perform better during recessions.

Existing studies do not clearly predict whether conglomerates are more competitive than single-segment firms under intense competition, where internal capital markets impact product market competition. Cestone and Fumagalli (2005) indicate that business groups' internal capital markets can allocate more resources to subsidiaries facing competition, thereby making group firms more likely to enter or stay in the market. On the other hand, the model also suggests that internal resource reallocation hinders group-affiliated firms' competitiveness when group headquarters engage in winner-picking owing to scarce resources. This is similar to the commitment cost of internal capital markets suggested by Matsusaka and Nanda (2002), who reveal that internal capital markets reduce conglomerates' competitiveness, as they may withdraw financial support from a division facing more intense competition. Mathews and 
Robinson (2008) outline the strategic impacts of internal capital markets in a conglomerate setting and develop an equilibrium model where firm boundaries are endogenously shaped after considering the strategic impacts.

A few studies empirically explore the effects of access to internal capital markets on competitive outcomes. Khanna and Tice (2001) demonstrate that conglomerate segments quickly respond to the entry of Walmart in a market, irrespective of whether they decide to stay or exit. While they test how conglomerate segments versus single-segment firms react differently to tougher competition, the evidence is limited to the discount store industry. Boutin et al. (2013) showed that conglomerates' financial backing deters entry to their market. Kim (2014) documents that firms supported by weak internal capital markets lose market shares to those backed by strong internal capital markets. Neither of these two studies directly tests the impact of internal capital markets in response to intensified competition.

Several studies use intensified import competition as an exogenous change in the level of competition. $\mathrm{Xu}$ (2013) presents evidence that firms decrease leverage in response to expected decreased profitability caused by increased import penetration. Fresard and Valta (2012) show that tariff reductions, which increase foreign competition, cause firms to reduce capital and R\&D investment and increase cash reserves. Valta (2012) also uses large tariff reductions to show that bank debt becomes costlier when firms encounter tougher competition. Huang and Kim (2019) document that supplier firms reduce their leverage in response to a reduction of tariff rates [4].

In particular, two recent studies examined large tariff reductions and how conglomerates react differently than single-segment firms when the level of competition increases. Bai (2019) shows that conglomerates withstand import competition through less reduction in productivity compared to single-segment firms, and conglomerates are more aggressive in their response to increased competition when the competitive shocks occur in core businesses. Swanburg (2014) shows that conglomerate divisions reduce investment more compared to standalone firms when facing intensified import competition.

\section{Methodology and data}

\subsection{Empirical strategy}

To explore the relationship between product market outcomes and organization types, it is important to identify an exogenous variation in product market competition that is not caused by a firm. While domestic competition is largely affected by incumbent firms' performance and strategies, import competition is driven by trade barriers and rivals' strategies. Specifically, China's WTO accession provides a natural experiment setting to test the effect of an exogenous increase in Chinese import competition on US firms (Pierce and Schott, 2016; Bloom et al., 2016).

US imports from non-market economies such as China are subject to higher tariffs (known as "non-normal trade relations (NTR)") set under the Smoot-Hawley Tariff Act of 1930, while imports from WTO members have lower tariffs, "NTR." Although China was not a WTO member, the USA began granting NTR rates to China in 1980, though annual approval by the US Congress was required for renewal, which created uncertainty about the longevity of low tariffs. However, China's accession to the WTO in December 2001 eliminated this uncertainty, and Chinese exporters made investments that substantially increased competition in the US markets. Pierce and Schott (2016) show there was an increase in import competition, which leads to reduced employment in the USA after the WTO accession. 
JDQS 28,2

This study uses the NTR gap, following Pierce and Schott (2016), to measure variations in the increase of Chinese import competition by industry. The NTR gap represents the difference between the non-NTR rate to which tariffs would have risen if annual renewal had failed and the NTR tariff rate that was locked in by PNTR:

$$
\text { NTR gap }=\text { Non-NTR rate }- \text { NTR rate }
$$

Most of the variations in the NTR gap across industries are derived from variation in nonNTR rates, which were set 70 years before NTR implementation. Following Pierce and Schott (2016), this study uses NTR gaps for 1999, one year before the passage of PNTR.

\subsection{Data and empirical model}

The data sample is from the Compustat Industry Segment data base and identifies firms as conglomerates every year if the Compustat business segment files report positive assets and sales in more than one four-digit standard industrial classification (SIC) industry during the year [5]. Following Berger and Ofek (1995), the sample is restricted to firms having total segment sales within $1 \%$ of the firm's total sales annually. The sample excludes firms in financial industries (SIC 6000-6999). Finally, the segment sample was merged with the NTR gap calculated by Pierce and Schott (2018) based on four-digit SICs, and observations with missing NTR gap were eliminated.

The link between firm boundaries and product market performance was examined using a difference-in-differences-in-differences approach. I first measure whether changes of corporate performance in industries with higher NTR gaps (first difference) are different after the imposition of PNTR (second difference) compared to its counterpart with lower NTR gaps. Then, I compare the changes between conglomerate segments and single-segment firms (third difference). Segment fixed effects capture the impact of time-invariant firm (segment) characteristics, and year fixed effects account for aggregate shocks that affect all industries equally. I estimate the following equation:

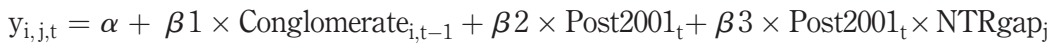

$$
\begin{aligned}
& +\beta 3 \times \text { Conglomerate }_{\mathrm{i}, \mathrm{t}-1} \times \text { Post2001 } \times \mathrm{NTrgap}_{\mathrm{j}}+\beta 4 \times \mathrm{NTRgap}_{\mathrm{j}}+\gamma \times \text { Controls }+\mu_{\mathrm{t}}+\mu_{\mathrm{i}}
\end{aligned}
$$

where subscript $i$ refers to the segment, subscript $j$ refers to the industry, subscript $t$ refers to time in years, $\mu_{t}$ refers to the year fixed effects and $\mu_{i}$ refers to segment fixed effects. The dependent variable $y$ is a measure of segment performance, segment sales growth and segment cash flows. Segment sales growth is the change in net sales divided by previous year net sales, and segment cash flows is earnings before interest depreciation and taxes divided by assets. The analysis treats years after 2001 as being "post-PNTR," which is captured by Post2001, a dummy variable taking the value of 1 for years greater than 2001. NTRgap is defined in the previous section. Conglomerate is a dummy variable that takes a value of one for segments of conglomerates. In the equation, $\beta_{3}$ is the measure of the differential impact of import penetration on performance between conglomerate segments and single-segment firms. Controls include lagged values of segment sales growth, segment cash flows, segment size, segment industryQ and segment investment. size is the logarithm of segment assets, and investment is the segment capital expenditure divided by assets. 
Industry $Q$ is the average Tobin's $\mathrm{Q}$ in a four-digit SIC industry. The standard errors in all specifications are clustered at the firm level and are robust to heteroscedasticity.

The final sample includes observations without missing value of variables defined above. The final sample includes annual firm (segment)-level observations from 1997 to 2005, which consists of 27,797 firm-year observations. Table 1 provides details of the sample. Panel A shows sample distribution by industry (two-digit SIC). The sample represents various industries in the USA, and about $50 \%$ of the sample observations are from manufacturing industries. Panel A of Table 2 reports summary statistics of the main variables; all variables are winsorized at the top and bottom $1 \%$. Panel B of Table 2 compares conglomerate segments to single-segment firms. There are 8,582 conglomerate observations and 19,215 single-segment observations. Mean value comparison suggests that single-segment firms on average show greater sales growth than conglomerate segments. Single-segment firms operate in industries with higher growth potential, as indicated by the higher industry $\mathrm{Q}$ values. On average, conglomerate segments are larger and have higher profitability.

\section{Empirical results}

\subsection{Effect of the Chinese WTO accession}

Baseline results reported in Table 3 compare product market performance of single-segment firms and conglomerate segments. In the first two columns, the dependent variables are salesgrowth and cashflows. The positive coefficient of conglomerate in Columns (1) and (2) indicates that, on average, conglomerate segments have higher sales growth and profitability than single-segment firms. The negative coefficient of Post2001 $\times$ NTRgap indicates that an increase in Chinese imports results in decreased sales growth and profitability. Conversely, the positive coefficient of Conglomerate $\times$ Post2001 $\times$ NTRgap indicates that an increase in Chinese imports results in conglomerate segments performing better than single-segment firms. The sum of the coefficients on Post2001 $\times$ Ntrgap and Conglomerate $\times$ Post2001 $\times$ NTRgap is negative, indicating that conglomerate segments also experience declining performance when they face intense import competition.

Columns (3) and (4) include industry fixed effect rather than the segment fixed effect. The NTRgap varies by industry, and industry factors affect the proportion of conglomerate segments in that industry. The coefficient of conglomerate $\times$ Post2001 $\times$ NTRgap is statistically and economically significant.

The coefficients of the control variables indicate that segments in industries with higher growth potential (positive coefficient of industry $Q$ in salesgrowth regressions and negative coefficient of industryQ in cashflows regressions) have higher sales growth and lower profitability. While larger segments have less growth in sales, their

\begin{tabular}{lrc}
\hline Two-digit SIC & $N$ & \% of sample \\
\hline $10,12,13,15,16,17$ & 1,693 & 6.09 \\
$20,21,22,24,25,26,27,28,29$ & 6,044 & 21.74 \\
$30,32,33,34,35,36,37,38,39$ & 13,009 & 46.80 \\
$42,45,47,48,49$ & 1,338 & 4.81 \\
$50,51,52,55,56,57,58,59$ & 927 & 3.33 \\
$70,73,78,79$ & 4,704 & 16.92 \\
80,87 & 82 & 0.29
\end{tabular}

Note: This table reports industry distribution of my sample by two-digit SIC

Table 1.

Sample description: distribution of firmyear observations by industry 


\begin{tabular}{|c|c|c|c|c|c|c|}
\hline \multirow{5}{*}{$\begin{array}{l}\text { JDQS } \\
28,2\end{array}$} & & $N$ & Mean & $25 \%$ & Median & $75 \%$ \\
\hline & Panel A: all segments & & & & & \\
\hline & Salesgrowth & 27,797 & 0.486 & -0.096 & 0.059 & 0.302 \\
\hline & Cashflows & 27,797 & -0.126 & 0 & & 0.022 \\
\hline & Investment & 27,797 & 0.063 & 0.015 & 0.036 & 0.074 \\
\hline \multirow{3}{*}{56} & Size & 27,797 & 4.274 & 2.653 & 4.199 & 5.897 \\
\hline & IndustryQ & 27,797 & 2.148 & 1.645 & 2.162 & 2.606 \\
\hline & $\begin{array}{l}\text { Conglomerate } \\
\text { Ntrgap }\end{array}$ & $\begin{array}{l}27,797 \\
27,797\end{array}$ & $\begin{array}{l}0.309 \\
0.328\end{array}$ & $\begin{array}{l}0 \\
0.284\end{array}$ & $\begin{array}{l}0 \\
0.361\end{array}$ & $\begin{array}{l}1.00 \\
0.378\end{array}$ \\
\hline
\end{tabular}

Panel B: comparison between conglomerate segments and single-segment firms

\begin{tabular}{lcccrrc} 
& \multicolumn{3}{c}{$\begin{array}{c}\text { Conglomerate } \\
\text { Mean }\end{array}$} & Median & $N$ & Single segment \\
Salesgrowth & $\mathbf{N}$ & 0.414 & 0.040 & 19,215 & 0.519 & Median \\
Cashflows & 8,582 & -0.006 & 0 & 19,215 & -0.180 & 0 \\
Investment & 8,582 & 0.059 & 0.037 & 19,215 & 0.064 & 0.036 \\
Size & 8,582 & 4.905 & 5.033 & 19,215 & 3.992 & 3.942 \\
IndustryQ & 8,582 & 1.902 & 1.828 & 19,215 & 2.258 & 2.262
\end{tabular}

Notes: This table presents the descriptive statistics for main variables of the analyses. The definition of the

Table 2.

Summary statistics

variables is described in the Appendix. Panel A reports the number of observations, mean, bottom $25 \%$, median and the $75 \%$ percentile of the entire sample. Panel B reports key statistics for conglomerate segments and single-segment firms separately

profitability is greater than smaller segments. The coefficients of investment indicate that higher investment boosts sales growth, though it may decrease profitability.

The results indicate that conglomerate segments have higher sales growth and cash flow compared to single-segment firms when confronted by import competition. The significant difference in performance between single-segment firms and conglomerate segments is obtained after controlling segment characteristics. Furthermore, firm fixed effects control unobservable time-invariant differences between single-segment and multi-segment firms [6]. Given the fixed market size in the short term, higher sales growth and profitability suggest conglomerate segments may gain market share when competition intensifies from increased Chinese imports. The higher sales growth and cash flow support the argument that conglomerate segments can compete more aggressively owing to their deep pockets of internal capital markets, compared to single-segment firms. The results are consistent with that conglomerate segments cross-subsidize and hence less financially constrained when facing intense competition. However, the result does not support the hypothesis that conglomerate headquarters pull resources out of those facing tough competition.

\subsection{Effect conditional on the level of existing competition before the event}

In Section 4.2, I repeat the tests after differentiating between industries with high and low competition levels and the study to test whether the level of competition affects conglomerates' support of segments. Firms in competitive industries are likely to have lower margins and lower cash flows, and they are more likely to depend on external financial markets and face greater constraints when competition intensifies. In this situation, it is an empirical question whether conglomerate divisions will perform better than single-segment firms when headquarters engage in winnerpicking to allocate resources. To determine if Chinese import competition 


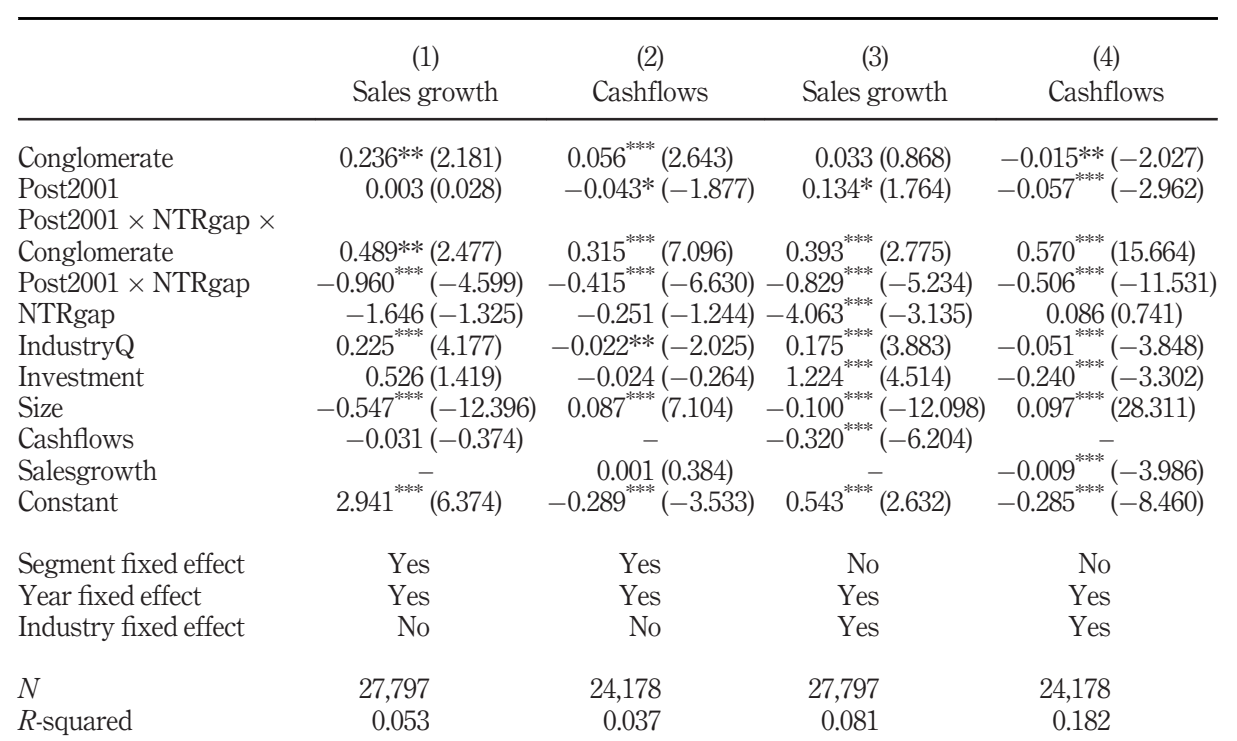

Notes: This table presents the regression results of whether segment sales growth and cash flows are different depending on conglomeration in industries facing intense Chinese import competition (Conglomerate $\times$ Post2001 $\times$ NTRgap). The sample includes segments of US firms obtained from Compustat Industrial Segments data base. The definition of the variables is described in the Appendix. Tstatistics based on robust standard errors are reported in parentheses. *; **; and *** denote statistical significance at the 10,5 and $1 \%$ levels, respectively

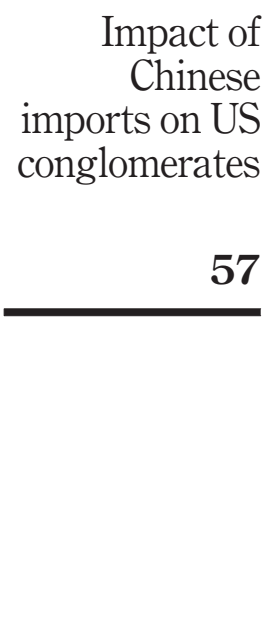

Table 3.

Performance of conglomerate segments and singlesegment firms in the periods before and after the Chinese WTO accession

disproportionately affects firms in industries that were already competitive before the WTO accession, I use two measures of existing competition:

(1) Herfindahl-Hirschman index (HHI), which is calculated using Compustat firms; and

(2) import penetration index (IPI), which is calculated as imports divided by domestic production plus imports.

If the HHI measured in 2000 is below the sample median or the IPI 2000 value is above the sample median, the industry is classified as having high competition.

The regression results on whether the different performances reported in Table 3 are conditional on the level of competition before the WTO accession are reported in Table 4. When the dependent variable is sales growth, the coefficient of Conglomerate $\times$ Post $2001 \times$ NTRgap is statistically significant and positive only in sub-sample regressions for firms in industries with low competition. In regressions of cash flows, the coefficient is significant only in the sample of low competition when the competition is measured by HHI. When existing competition is measured by IPI, the coefficient is significant in both subsamples, but the magnitude is slightly larger for low competition. This indicates that conglomerate segments do not perform better than single-segment firms when existing competition is intense. Conglomerate headquarters provide support to divisions that were operating in less competitive industries. The segments with existing intense competition and that anticipate 
JDQS

28,2

58

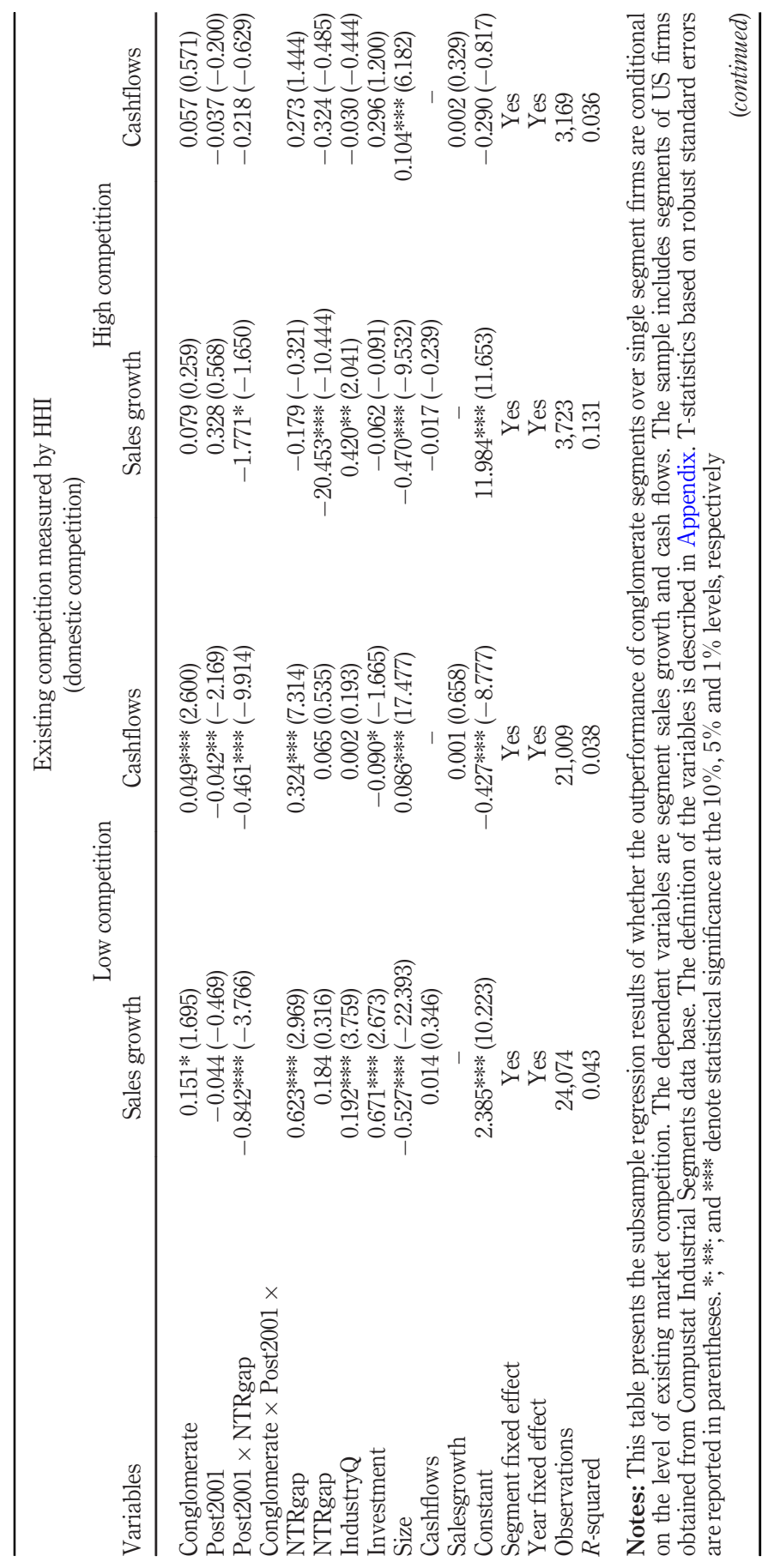

Table 4.

Does the level of existing competition matter in determining conglomerate performance? 


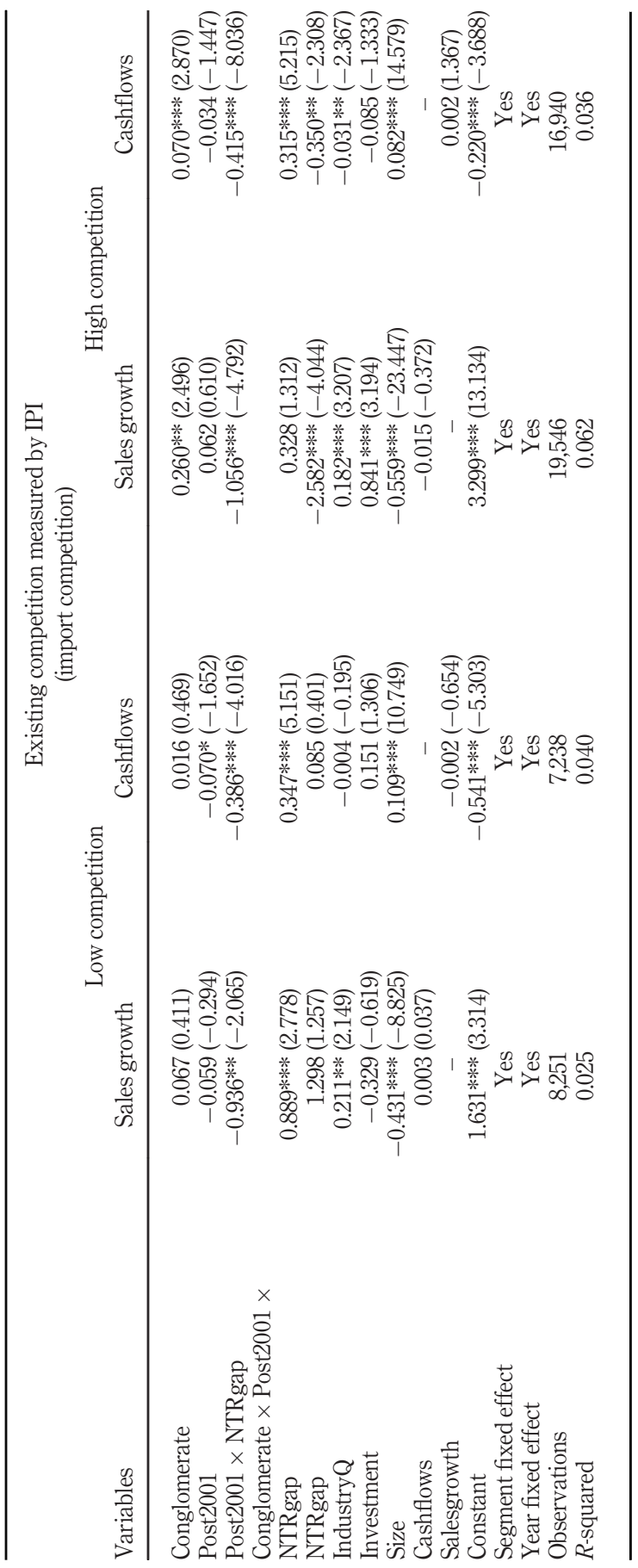


increased competition are not allocated additional resources. This result may suggest that conglomerates engage in winner-picking and focus on core segments with promising prospects.

\section{Conclusion}

This study provides the first empirical evidence that conglomerate segments perform better than single-segment firms during periods of heightened import competition. The findings support a key economic issue - firm boundaries influence firm policies. Furthermore, this study demonstrates that conglomerate internal capital market allocation is conditional on existing competition, indicating that conglomerates engage in winner-picking. The evidence is consistent with Gopalan and Xie (2011), who reported that conglomerates support segments with greater past performance during industrial distress. Overall, this study suggests that internal capital markets benefit conglomerate segments during difficult times and internal resource allocation is efficient.

\section{Notes}

1. See Stein (2003) for reviews.

2. For earlier studies, see DeRosa and Goldstein (1981), Katics and Petersen (1994), and Pugel (1980).

3. This study focuses on business diversification. See Seok et al. (2018) and Kim (2013) for geographical diversification and its effect in Korea.

4. See Choe (2004), which examines the effect of global trade deregulation on the Korean financial market.

5. All segments within a firm that share a common four-digit SIC code are aggregated into one segment.

6. The possibility exists that endogenous selection of conglomerate segments may cause better performance during difficult times.

\section{References}

Bai, J. (2019), "Organizational form and trade liberalization: Plant-Level evidence”, Working paper.

Belenzon, S. and Berkovitz, T. (2010), "Innovation in business groups", Management Science, Vol. 56 No. 3, pp. 519-535.

Berger, P.G. and Ofek, E. (1995), "Diversifications' effect on firm value”, Journal of Financial Economics, Vol. 37 No. 1, pp. 39-65.

Bloom, N., Draca, M. and Reenen, J.V. (2016), “Trade induced technical change? The impact of Chinese imports on innovation, IT, and productivity", The Review of Economic Studies, Vol. 83 No. 1, pp. 87-117.

Boutin, X., Cestone, G., Fumagalli, C., Pica, G. and Serrano-Velarde, N. (2013), "The deep pocket effect of internal capital markets", Journal of Financial Economics, Vol. 109 No. 1, pp. 122-145.

Cestone, G. and Fumagalli, C. (2005), "The strategic impact of resource flexibility in business groups", Rand Journal of Economics, Vol. 36, pp. 193-214.

Choe, H. (2004), "The feasibility of the steel futures contract and the impacts of steel industry", Korean Journal of Futures and Options, Vol. 12, pp. 51-72.

Coase, R. (1937), “The nature of the firm”, Economica, Vol. 4 No. 16, pp. 386-405.

DeRosa, D.A. and Goldstein, M. (1981), "Import discipline in the US manufacturing sector", Staff Papers - International Monetary Fund, Vol. 28 No. 3, pp. 600-634. 
Gopalan, R. and Xie, K. (2011), "Conglomerates and industry distress", Review of Financial Studies, Vol. 24 No. 11, pp. 3642-3687.

Huang, Q. and Kim, R. (2019), "Capital structure decisions along the supply chain: evidence from import competition", Journal of International Business Studies, Vol. 50 No. 6, pp. 873-894.

Katics, M. and Petersen, B.C. (1994), "The effect of rising import competition on market power: a panel study of US manufacturing”, The Journal of Industrial Economics, Vol. 42 No. 3, pp. 277-286.

Khanna, N. and Tice, S. (2001), "The bright side of internal capital markets", The Journal of Finance, Vol. 56 No. 4, pp. 1489-1531.

Kim, Y. (2013), "Global diversification and hedging by high technology firms", Korean Journal of Futures and Options, Vol. 21, pp. 383-409.

Maksimovic, V. and Phillips, G. (2008), "The industry life cycle, acquisitions, and investments: Does firm organization matter?", The Journal of Finance, Vol. 63 No. 2, pp. 673-708.

Mathews, R.D. and Robinson, D.T. (2008), "Market structure, internal capital markets, and the boundaries of the firm", The Journal of Finance, Vol. 63 No. 6, pp. 2703-2736.

Matsusaka, J. and Nanda, V. (2002), "Internal Capital markets and corporate refocusing”, Journal of Financial Intermediation, Vol. 11 No. 2, pp. 176-211.

Pierce, J.R. and Schott, P.K. (2016), "The surprisingly swift decline of US manufacturing employment", American Economic Review, Vol. 106 No. 7, pp. 1632-1662.

Pugel, T.A. (1980), "Foreign trade and US market performance", The Journal of Industrial Economics, Vol. 29 No. 2, pp. 119-129.

Seok, S., Kim, T., Cho, H. and Kim, T. (2018), "A study on the effect of geographic diversification of firms on hedging activity using derivatives", Korean Journal of Futures and Options, Vol. 26, pp. 59-83.

Stein, J.C. (2003), “Agency, information and corporate investment”, In Constantinides, G.M.M.H and Stulz, R.M., (Eds). Handbook of the Economics of Finance, vol. 1A, Elsevier, Amsterdam: NorthHolland.

Swanburg, G. (2014), "Internal capital markets and competitive threats", Working paper.

Valta, P. (2012), "Competition and the cost of debt", Journal of Financial Economics, Vol. 105 No. 3, pp. 661-682.

\section{Further reading}

Kim, R. (2016), "Financial weakness and product market performance: internal capital market evidence", Journal of Financial and Quantitative Analysis, Vol. 51 No. 1, pp. 307-332.

$\mathrm{Xu}, \mathrm{J}$. (2012), "Profitability and capital structure: evidence from import penetration", Journal of Financial Economics, Vol. 106 No. 2, pp. 427-446. 


\section{Appendix}

Variable name

Salesgrowth

Cashflows

Size

Investment

IndustryQ

Conglomerate

Table A1.

Variable definitions
Post2001

NTRgap

\section{Definition}

Segment sales minus segment sales of previous year, divided by the previous year's segment sales

The ratio of segment operating income before depreciation to segment total assets The logarithm of segment total assets

Segment capital expenditure divided by total assets

Average Tobin's Q of all firms in an industry based on four-digit-SIC

(Tobin's Q is The ratio of market value of total assets to the book value of total assets, where market value of total assets is the sum of book value of total assets and the market value of equity less the book value of equity)

A dummy variable that identifies firms with more than one segment with positive sales and assets in more than one four-digit-SIC industries

A dummy variable indicating years from 2001 onward

Non-NTR rate - NTR rate

\section{Corresponding author}

Ryoonhee Kim can be contacted at: ryoonkim@ssu.ac.kr

For instructions on how to order reprints of this article, please visit our website: 